\title{
Analisis Faktor-Faktor yang Mempengaruhi Pengambilan Keputusan Petani Dalam Menggunakan Benih Hibrida Pada Usahatani Jagung (Studi Kasus di Desa Patokpicis, Kecamatan Wajak, Kabupaten Malang)
}

\section{Analysis of Factors Affecting Farmer's Decision Making to Use Hybrid Seed on Corn Farming (Case Study at Patokpicis Village, Wajak District, Malang Regency)}

\author{
Rr. Myristica Ayu Apriliana ${ }^{1^{*}}$, Moch. Muslich Mustadjab ${ }^{2}$ \\ Jurusan Sosial Ekonomi, Fakultas Pertanian, Universitas Brawijaya, Jl. Veteran, Malang 65145, \\ Indonesia.
}

Diterima: 25 Juli 2016; Direvisi: 26 Juli 2016; Disetujui: 29 Juli 2016

\begin{abstract}
ABSTRAK
Goal dalam penelitian ini adalah memberikan masukan dalam upaya peningkatan pendapatan petani jagung di Desa Patokpicis dengan beralih menggunakan benih hibrida. Penelitian ini penting dilakukan karena terdapat perbedaan pendapatan antar petani jagung yang didasarkan pada keputusan petani dalam mempertimbangkan jenis benih yang digunakan. Keputusan untuk menggunakan benih hibrida dapat meningkatkan produksi dan pendapatan petani di Desa Patokpicis. Kenyataannya tidak semua petani di Desa Patokpicis menggunakan benih hibrida, terdapat beberapa petani yang tetap menggunakan benih lokal. Keputusan petani untuk menggunakan benih hibrida berpeluang meningkatkan pendapatan usahatani dibandingkan keputusan menggunakan benih lokal, sehingga perlu diteliti lebih lanjut. Dengan menggunakan analisis perbandingan pendapatan usahatani, analisis regresi logistik, dan analisis fungsi pendapatan dapat menyimpulkan sejauh mana faktor-faktor yang berpengaruh terhadap keputusan petani dalam menggunakan benih hibrida dapat meningkatkan pendapatan petani.
\end{abstract}

Kata kunci: petani jagung; benih hibrida; keputusan; pendapatan

\section{ABSTRACT}

Goal of this research is giving recommendations to increase corn farmer's income in Patokpicis village by using hybrid seed. This research important to do because there are differences income among corn farmers based on the farmer's decision to consider the type of seed used. The decision to use hybrid seeds can increase production and income of farmers in the Patokpicis village. In fact not all farmers using hybrid seed in the Patokpicis village, there are some farmers still use local seed.The decision of farmers to use hybrid seeds has a chance of raising revenue than the decision of the use of the seed of local farming, so it needs further study. By using a comparative analysis of farm income, logistic regression analysis, and analysis functions can infer the extent to which revenue the factors that influence the decision of farmers to use hybrid seeds can increase farmers' income.

Keywords: corn farmer; hybrid seeds; decision; income

\section{Pendahuluan}

Jagung merupakan salah satu tanaman pangan kedua setelah padi yang digunakan sebagai bahan pangan, pakan ternak, dan bahan baku industri. Kebutuhan jagung di Indonesia dari tahun ke tahun terus meningkat seiring dengan terus bertambahnya jumlah penduduk.

\footnotetext{
"Penulis Korespondensi.

E-mail : myristicaayu@gmail.com
}

Menurut data SUSENAS (2014) kebutuhan konsumsi jagung pada tahun 2013 sebesar 1,469 $\mathrm{kg} / \mathrm{kapita} /$ tahun, sedangkan kebutuhan konsumsi jagung pada tahun 2014 sebesar 1,553 $\mathrm{kg} / \mathrm{kapita/tahun}$.

Peningkatan kebutuhan konsumsi jagung tersebut perlu diimbangi dengan peningkatan produksi. Salah satu upaya yang dapat dilakukan untuk meningkatkan produksi jagung yaitu dengan menerapkan inovasi teknologi melalui penggunaan benih unggul. Menurut Sembiring 
(2015) benih unggul yang dimaksud yaitu benih jagung hibrida, dimana meningkatkan produksi jagung karena memiliki tingkat produktivitas yang tinggi. Hal ini diperkuat dengan pendapat Mubarrakan, dkk (2012) bahwa benih jagung hibrida memiliki tingkat produksi rata-rata sebesar 8 ton/ha. Sehingga penerapan inovasi teknologi pada kegiatan usahatani jagung dengan menggunakan benih hibrida berpotensi untuk meningkatkan produksi jagung nasional.

Desa Patokpicis merupakan salah satu desa yang sebagian petaninya telah menggunakan benih hibrida pada kegiatan usahatani jagung. Pada tahun 2014, Desa Patokpicis mampu memproduksi jagung hingga 2.117 ton dengan produktivitas 7,3 ton/ha (UPT PPL Wajak, 2015). Besarnya produktivitas tersebut dipengaruhi oleh jenis benih yang digunakan yaitu benih hibrida pada kegiatan usahatani jagung.

Petani jagung di Desa Patokpicis telah menggunakan benih hibrida sejak tahun 2012 . Benih hibrida tersebut berasal dari subsidi pemerintah yang diberikan secara gratis kepada petani setempat. Varietas benih jagung hibrida yang diberikan kepada petani, antara lain varietas Pertiwi, Jaya, Bisi 2, Pioner, dan SHS. Adanya pemberian subsidi benih hibrida tersebut bertujuan agar hasil produksi jagung di Desa Patokpicis meningkat. Sebab menurut Warisno (1998) penggunaan benih jagung hibrida dapat menghasilkan produksi tinggi mencapai 6-9 ton/ha.

Pada kenyataannya tidak semua petani jagung di Desa Patokpicis beralih menggunakan benih hibrida. Namun masih terdapat petani jagung yang tetap menggunakan benih non hibrida. Hal ini dikarenakan biaya yang dikeluarkan untuk usahatani jagung hibrida lebih mahal dibandingkan non hibrida. Sedangkan petani jagung di Desa Patokpicis terkendala pada modal usaha dan tidak berani mengambil resiko untuk mengambil keputusan. Selain itu keterlambatan penyaluran subsidi benih hibrida menyebabkan petani menggunakan benih non hibrida karena penyaluran subsidi benih melewati awal usim tanam jagung di Desa Patokpicis.

Biaya produksi yang tinggi dan keterlambatan penyaluran benih hibrida menyebabkan petani jagung di Desa Patokpicis dihadapkan dengan suatu dilema mengenai pemilihan jenis benih yang akan digunakan pada kegiatan usahataninya. Sehingga petani harus melakukan prediksi yang tepat dalam menentukan jenis benih yang akan digunakan karena nantinya berpengaruh terhadap pendapatan yang diterima petani. Pendapatan petani jagung hibrida lebih tinggi dibandingkan pendapatan petani non hibrida. Hal ini dikarenakan penggunaan benih non hibrida menghasilkan produktivitas yang berdaya hasil rendah yaitu 1,5-2 ton/Ha Sarasutha (1998) dalam Hadijah (2009).

Pemilihan jenis benih jagung di Desa Patokpicis didasarkan pada keputusan petani. Menurut Suratiyah (2006), petani sebagai manajer harus dapat mengambil keputusan dengan berbagai pertimbangan ekonomis. Menurut Makeham dan Malcolm (1991) bahwa pengambilan keputusan biasanya berkaitan dengan suatu atau serangkaian jalannya tindakan dari sejumlah alternatif, yang akan menuju pencapaian beberapa tujuan petani. Menurut Soekartawi (1988) keputusan yang diambil petani didasarkan pada faktor-faktor, seperti jumlah anggota keluarga, kelompok tani, umur, pendidikan, pendapatan, dan luas lahan usahatani.

Keputusan petani jagung di Desa Patokpicis untuk menggunakan benih hibrida atau non hibrida tergantung pada kesadaran petani untuk memaksimumkan pendapatan usahataninya. Semakin banyak petani yang memutuskan untuk menggunakan benih hibrida, maka pendapatan yang diterima petani akan semakin meningkat. Namun semakin banyak petani yang memutuskan untuk menggunakan benih non hibrida, maka pendapatan yang diterima cenderung stabil. Oleh karenanya, kegiatan usahatani jagung non hibrida tidak dapat meningkatkan pendapatan petani di Desa Patokpicis.

Sudah banyak penelitian tentang faktorfaktor yang mempengaruhi keputusan petani. Namun belum ada penelitian khusus yang membahas mengenai faktor-faktor yang mempengaruhi keputusan petani dalam menggunakan benih jagung hibrida.

Berdasarkan uraian di atas, dirasa perlu diadakan penelitian mengenai faktor-faktor yang mempengaruhi keputusan petani dalam menggunakan benih hibrida pada usahatani jagung di desa Patokpicis agar diperoleh masukan dalam upaya peningkatan pendapatan petani jagung. Sehingga masalah penelitian ini dapat dirumuskan sebagai berikut "sejauh mana keputusan petani menggunakan benih hibrida berpengaruh pada pendapatan usahatani jagung", maka tujuan dilakukannya penelitian ini adalah 1) menganalisis pendapatan usahatani jagung hibrida dan usahatani jagung non hibrida di 
daerah penelitian, 2) menganalisis faktor-faktor yang mempengaruhi pengambilan keputusan petani untuk menggunakan benih hibrida pada usahatani jagung di daerah penelitian dan, 3) menganalisis faktor-faktor yang mempengaruhi pendapatan usahatani jagung di daerah penelitian.

\subsection{Telaah Penelitian Terdahulu dan Teori yang Relevan}

Penelitian yang dilakukan oleh Dilla (2014) menunjukkan bahwa pendapatan petani jagung yang menggunakan pupuk organik lebih besar dibandingkan dengan pendapatan petani yang menggunakan pupuk anorganik dan faktor yang berpengaruh pada pengambilan keputusan petani untuk menggunakan pupuk pada usahatani jagung adalah penyuluhan, sedangkan faktor pendapatan, umur, luas lahan, dan pengetahuan tidak memiliki pengaruh terhadap keputusan petani. Menurut Makeham dan Malcolm (1991) bahwa pengambilan keputusan biasanya berkaitan dengan suatu atau serangkaian jalannya tindakan dari sejumlah alternatif, yang akan menuju pencapaian beberapa tujuan petani. Shinta (2011) mengatakan bahwa pengambilan keputusan petani yang berani menanggung resiko untuk mengalokasikan faktor-faktor produksi pada usahataninya maka akan lebih optimal dalam mengalokasikan faktor produksi.

\subsection{Kerangka Konsep Penelitian}

Desa Patokpicis, Kecamatan Wajak, Kabupaten Malang merupakan daerah penghasil jagung yang petaninya dihadapkan dengan pilihan alternatif, yaitu penggunaan jenis benih (benih hibrida dan non hibrida). Biaya yang dikeluarkan untuk usahatani jagung hibrida lebih mahal dibandingkan jagung non hibrida dan keterlambatan penyaluran subsidi benih menjadi kendala bagi petani. Berdasarkan permasalahan tersebut menyebabkan petani jagung di Desa Patokpicis dihadapkan pada keputusan untuk menggunakan benih hibrida atau non hibrida pada usahataninya. Pengambilan keputusan petani tersebut dipengaruhi oleh beberapa faktor, yaitu umur, tingkat pendidikan, pengalaman usahatani, luas lahan, pendapatan usahatani, kebutuhan pupuk, dan keikutsertaan kelompok tani. Faktor-faktor yang mempengaruhi pengambilan keputusan di atas, dianalisis menggunakan regresi logistik yang nantinya dapat digunakan sebagai rekomendasi petani dalam mengambil keputusan yang tepat untuk kegiatan usahataninya. Keputusan petani untuk menggunakan benih hibrida pada usahatani jagung diharapkan mampu meningkatkan pendapatan dalam rumah tangga petani. Berdasarkan pendapatan yang diperoleh dari usahatani jagung hibrida dan jagung non hibrida maka dilakukan analisis pendapatan usahatani jagung hibrida dan jagung non hibrida. Analisis ini dilakukan untuk mengetahui tingkat pendapatan pada masing-masing usahatani dengan menggunakan uji beda rata-rata. Tingkat pendapatan usahatani jagung tersebut diduga dipengaruhi oleh beberapa faktor, yaitu hasil produksi, biaya benih, biaya pupuk, biaya tenaga kerja, dan jenis penggunaan benih. Pengujian yang dilakukan unuk mengetahui pengaruh faktor tersebut terhadap pendapatan usahatani jagung adalah analisis regresi berganda.

Berdasarkan latar belakang, rumusan permasalahan, dan kerangka pemikiran yang telah diuraikan, dirumuskan hipotesis penelitian sebagai berikut:

a. Pendapatan usahatani jagung hibrida lebih tinggi dibandingkan pendapatan usahatani jagung non hibrida.

b. Tingkat pendidikan, pengalaman usahatani, luas kepemilikan lahan, pendapatan, kebutuhan pupuk, dan keikutsertaan kelompok tani berpengaruh positif terhadap pengambilan keputusan petani untuk menggunakan benih hibrida pada usahatani jagung. Sedangkan umur petani berpengaruh negatif terhadap pengambilan keputusan petani untuk menggunakan benih hibrida pada usahatani jagung.

c. Hasil produksi dan jenis benih yang digunakan (benih jagung hibrida dan benih jagung non hibrida) berpengaruh positif terhadap pendapatan usahatani jagung. Sedangkan biaya benih, biaya pupuk, dan biaya tenaga kerja berpengaruh negatif terhadap pendapatan usahatani jagung.

\section{Metode Penelitian}

Penelitian ini dilakasanakan di Desa Patokpicis, Kecamatan Wajak, Kabupaten Malang, Penentuan lokasi penelitian dilakukan secara purposive dengan pertimbangan Desa Patokpicis merupakan daerah potensi pengembangan tanaman jagung di Kecamatan Wajak dan petani jagung di daerah tersebut berada pada penggunaan jenis benih yang berbeda yaitu benih hibrida dan lokal. Jumlah populasi petani dalam penelitian ini adalah 48 petani, sehingga semua petani dijadikan 
responden. Metode analisis data dalam penelitian ini digunakan untuk menjawab tujuan penelitian, sebagai berikut:

Tujuan 1 : Analisis Tingkat Pendapatan Usahatani Jagung Hibirda dan Usahatani Jagung Non hibrida

Analisis pendapatan dilakukan dengan cara membandingkan rata-rata pendapatan dari masing-masing usahatani yang menggunakan benih hibrida dan menggunakan benih non hibrida. Kemudian diuji menggunakan uji beda rata-rata, dengan langkah-langkah sebagai berikut.

a. Membuat hipotesa statistik yang diajukan, antara lain:

1) $\mathrm{H}_{0}: \mu_{1}=\mu_{2}$

2) $\mathrm{H}_{1}: \mu_{1}>\mu_{2}$

b. Menguji nilai varians dari masing-masing pendapatan usahatani jagung hibrida dan jagung non hibrida dengan Uji $F$ dengan rumus berikut ini.

$$
F_{\text {hitung }}=\frac{S_{1}^{2}}{S_{2}^{2}}
$$

c. Melakukan uji t

1) Jika thit $>$ t tabel, pada $\alpha=0,01,0,05$, dan $0,10\left(\mathrm{n}_{1}+\mathrm{n}_{2}-2\right)$ maka $\mathrm{H}_{1}$ diterima dan $\mathrm{H}_{0}$ ditolak yang artinya rata-rata tingkat pendapatan usahatani jagung hibrida lebih tinggi daripada rata-rata tingkat pendapatan usahatani jagung non hibrida.

2) Jika t hit $<\mathrm{t}$ tabel, pada $\alpha=0,01,0,05$, dan $0,10\left(\mathrm{n}_{1}+\mathrm{n}_{2}-2\right)$ maka $\mathrm{H}_{0}$ diterima dan tolak $\mathrm{H}_{1}$ yang artinya rata-rata tingkat pendapatan usahatani jagung hibrida sama dengan pendapatan usahatani jagung non hibrida.

Tujuan 2 : Analisis Faktor-Faktor yang Mempengaruhi Pengambilan Keputusan Petani

Analisis yang digunakan adalah analisis regresi logistik untuk mengetahui faktor-faktor yang mempengaruhi keputusan petani menggunakan benih hibrida. Model logit yang digunakan pada penelitian ini sebagai berikut.

$$
\begin{aligned}
\operatorname{Ln} Y= & \beta_{0}+\beta_{1} \operatorname{LnX} 1+\beta_{2} \operatorname{LnX} 2+\beta_{3} \operatorname{LnX} 3 \\
& +\beta_{4} \operatorname{LnX} 4+\beta_{5} \operatorname{LnX} 5 \\
& +\beta_{6} \operatorname{LnX} 6 \\
& +\beta_{7} D 1+e
\end{aligned}
$$

Dimana,

$$
\begin{gathered}
\operatorname{LnY}=\operatorname{Li}=\operatorname{Ln}\left(\frac{p i}{1-p i}\right) \\
\text { menggunakan benih hetani jagung } \\
\text { bibrida yang }
\end{gathered}
$$

dinyatakan dengan variabel dummy yang jika petani menggunakan benih hibrida diberi nilai 1 dan jika petani menggunakan benih non hibrida maka diberi nilai 0 .

$L i=\operatorname{Ln} \frac{1}{0}$, jika petani menggunakan benih hibrida

$L i=\operatorname{Ln} \frac{0}{1}$, jika petani tidak menggunakan benih hibrida

$\mathrm{X} 1$ = umur petani (tahun)

$\mathrm{X} 2$ = tingkat pendidikan (tahun)

$\mathrm{X} 3$ = pengalaman usahatani (tahun)

$\mathrm{X} 4=$ luas kepemilikan lahan (ha)

$\mathrm{X} 5=$ pendapatan usahatani $(\mathrm{Rp} / \mathrm{ha})$

$\mathrm{X} 6=$ kebutuhan pupuk $(\mathrm{kg} / \mathrm{ha})$

D1 = dummy keikutsertaan kelompok tani

$\mathrm{D} 1=1$, jika mengikuti kelompok tani

$\mathrm{D} 1=0$, jika tidak mengikuti kelompok tani

$\beta_{0} \quad=$ intersep

$\beta_{1}-\beta_{7}=$ koefisien regresi

$\mathrm{e} \quad=$ variabel pengganggu

Tujuan 3: Analisis Faktor-faktor yang Menpengaruhi Pendapatan Usahatani Jagung

Analisis yang digunakan untuk mengetahui faktor-faktor yang mempengaruhi pendapatan usahatani jagung adalah analisis fungsi pendapatan dengan model persamaan sebagai berikut.

$$
Y=\beta_{0}+\beta_{1} X 1+\beta_{2} X 2+\beta_{3} X 3+\beta_{4} X 4+
$$$$
\beta_{5} D b+e
$$

Dimana,

$\mathrm{Y} \quad=$ Pendapatan usahatani jagung dalam satu kali musim tanam $(\mathrm{Rp} / \mathrm{Ha})$

$\mathrm{X} 1=$ Hasil produksi jagung dalam satu kali musim tanam $(\mathrm{Rp} / \mathrm{Ha})$

$\mathrm{X} 2$ = Total biaya benih dalam satu kali musim tanam $(\mathrm{Rp} / \mathrm{Ha})$

$\mathrm{X} 3$ = Total biaya pupuk dalam satu kali musim tanam $(\mathrm{Rp} / \mathrm{Ha})$

$\mathrm{X} 4=$ Total biaya tenaga kerja dalam satu kali musim tanam $(\mathrm{Rp} / \mathrm{Ha})$

$\mathrm{Db}=$ Dummy jenis benih, dimana D1 $=1$, jika menggunakan benih hibrida $\mathrm{D} 1=0$, jika menggunakan benih non hibrida

$\beta_{0} \quad=$ intersep

$\beta_{1}-\beta_{5}=$ koefisien regresi

$\mathrm{e} \quad=$ variabel pengganggu 


\section{Hasil dan Pembahasan}

a. Menganalisis Tingkat Pendapatan Usahatani Jagung Hibrida dan Usahatani Jagung Non hibrida.

Tabel 1. Rata-rata Biaya Total, Produksi, Penerimaan, dan Pendapatan Per Hektar Usahatani Jagung Hibrida dan Usahatani Jagung Non hibrida dalam Satu Kali Musim Tanam di Desa Patokpicis, Kecamatan Wajak, Kabupaten Malang.

\begin{tabular}{|c|c|c|c|}
\hline$\overline{\text { No }}$ & Variabel & Usahatani Jagung Hibrida & Usahatani Jagung Non Hibrida \\
\hline 1. & Produksi Jagung $(\mathrm{kg} / \mathrm{Ha})$ & $4.715,26$ & $2.751,49$ \\
\hline 2. & Penerimaan $(\mathrm{Rp} / \mathrm{Ha})$ & $7.158 .643,00$ & $3.807 .375,99$ \\
\hline 3. & Biaya Total $(\mathrm{Rp} / \mathrm{Ha})$ & $4.217 .280,03$ & $2.552 .196,54$ \\
\hline & Pendapatan (Rp/Ha) & 2.941.362,97 & $1.255 .179,45$ \\
\hline & $\mathrm{t}_{\text {hitung }}=5,190$ & $\alpha=0,000$ & \\
\hline & $\mathrm{t}_{\text {tabel }} \alpha 0,01=2,410$ & $\mathrm{t}_{\text {tabel }} \alpha 0,05=1,678$ & $\mathrm{t}_{\text {tabel }} \alpha 0,10=1,300$ \\
\hline
\end{tabular}

Dari Tabel 1. diketahui rata-rata pendapatan per hektar usahatani jagung hibrida lebih tinggi dibandingkan rata-rata pendapatan usahatani jagung non hibrida. Pendapatan usahatani jagung hibrida sebesar Rp2.912.362,97/Ha dan usahatani jagung non hibrida sebesar Rp1.255.179,45/Ha dengan masing-masing presentase $70,01 \%$ dan $29,99 \%$. Perbedaan ini secara statistik nyata pada tingkat kepercayaan 99\% ( $\mathrm{t}$ hitung sebesar 5,190 $>\mathrm{t}$ tabel sebesar 2,410). Perbedaan tersebut dikarenakan jagung hibrida memiliki rata-rata produksi per hektar lebih tinggi dibandingkan rata-rata produksi tanaman jagung non hibrida. Produksi jagung hibrida sebesar $4.715,26 \mathrm{~kg} / \mathrm{ha}$ dan jagung non hibrida sebesar $2.751,49 \mathrm{~kg} / \mathrm{ha}$. Sesuai dengan pendapat Idrus (2009) bahwa jagung hibrida memiliki potensi produksi yang lebih tinggi mencapai 8 ton per ha daripada jagung non hibrida mencapai 2-3 ton per ha.

Perbedaan hasil produksi jagung hibrida dan jagung non hibrida berdampak pada penerimaan yang diperoleh petani jagung di daerah penelitian. Dari Tabel 1 diperoleh ratarata penerimaan petani jagung hibrida lebih tinggi dibandingkan rata-rata penerimaan petani jagung non hibrida. Rata-rata penerimaan usahatani jagung hibrida sebesar Rp7.158.643/Ha dan usahatani jagung non hibrida sebesar Rp3.807.375,99/Ha. Hal ini dikarenakan hasil produksi jagung hibrida lebih besar dibandingkan jagung non hibrida.

b. Menganalisis Faktor-faktor yang Mempengaruhi Pengambilan Keputusan Petani dalam Menggunakan Benih Hibrida Pada Usahatani Jagung.

Tabel 2. Hasil Uji Regresi Logit Faktor-faktor yang Mempengaruhi Keputusan Petani dalam Menggunakan Benih Hibrida Pada Usahatani Jagung di Desa Patokpicis

\begin{tabular}{|c|c|c|c|c|c|c|}
\hline Variabel & Koefisien & SE & Wald & (df) & Sig. & $\operatorname{Exp}(\mathbf{Y})$ \\
\hline LnUmur (X1) & -2.617 & 5.297 & .244 & 1 & .621 & .073 \\
\hline LnTingkat pendidikan (X2) & .851 & 1.041 & 668 & 1 & .414 & 2.341 \\
\hline LnPengalaman Usahatani (X3) & -2.037 & 1.548 & 1.730 & 1 & 188 & 130 \\
\hline LnLuas Lahan (X4) & -.407 & 1.107 & .135 & 1 & .713 & .665 \\
\hline LnPendapatan Usahatani Jagung (X5) & $2.363 * *$ & 1.057 & 4.999 & 1 & .025 & 10.626 \\
\hline LnKebutuhan Pupuk (X6) & $1.973 * *$ & 907 & 4.731 & 1 & .030 & 7.195 \\
\hline Keikutsertaan Kelompok Tani (D1) & $-10.578 * *$ & 4.703 & 5.059 & 1 & .024 & .000 \\
\hline Constant & -31.352 & 25.932 & 1.462 & 1 & .227 & .000 \\
\hline$P i$ & & & & & & 0,10 \\
\hline Chi Square $\left(X^{2}\right)$ & & & & & & 46.398 \\
\hline$-2 \log$ Likelihood Block Number $=0$ & & & & & & 66.542 \\
\hline$-2 \log$ Likelihood Block Number $=1$ & & & & & & 20.144 \\
\hline Negelkerke R Square & & & & & & .826 \\
\hline
\end{tabular}

Keterangan:

$* \quad$ : signifikansi pada taraf kepercayaan $99 \% \quad * * \quad$ : signifikansi pada taraf kepercayaan $95 \%$ 
*** : signifikansi pada taraf kepercayaan $90 \%$ $\mathrm{X}_{\text {tabel }}^{2}$ pada df $7(\alpha=1 \%) \quad: 24,322$

$\mathrm{X}^{2}$ tabel pada df $7(\alpha=10 \%) \quad: 12,017$

$\mathrm{X}^{2}$ tabel pada df $1(\alpha=5 \%) \quad: 3,841$

Tabel 2. merupakan hasil analisis regresi logit untuk menganalis faktor-faktor yang berpengaruh pada keputusan petani. Dari hasil uji regresi logistik yang disajikan pada Tabel 2., menunjukkkan bahwa Variabel pendapatan dan kebutuhan pupuk berpengaruh positif nyata terhadap keputusan petani untuk menggunakan benih hibrida. Hal ini dibuktikan dengan nilai koefisien regresi bertanda positif dan statistik wald > $\mathrm{X}^{2}$ tabel pada $\alpha=0,05$. Artinya semakin Artinya semakin tinggi pendapatan dan jumlah kebutuhan pupuk maka akan meningkatkan peluang petani untuk menggunakan benih hibrida.

Variabel keikutsertaan kelompok tani berpengaruh negatif nyata terhadap keputusan petani untuk menggunakan benih hibrida. Hal ini dibuktikan dengan nilai koefisien regresi bertanda negatif dan statistik wald $>\mathrm{X}^{2}$ tabel pada $\alpha=0,05$. Artinya setiap penambahan jumlah anggota kelompok tani maka tidak akan memberikan pengaruh bagi petani untuk menggunakan benih hibrida.

Variabel umur, tingkat pendidikan, pengalaman usahatani, dan luas lahan tidak tampak pengaruhnya terhadap keputusan petani untuk menggunakan benih hibrida yang dibuktikan dengan nilai statistik wald $<\mathrm{X}^{2}$ tabel
Variabel Dependen : Keputusan petani

$\mathrm{X}^{2}$ tabel pada df $7(\alpha=5 \%): 14,067$

$\mathrm{X}^{2}$ tabel pada df $1(\alpha=1 \%): 4,982$

$\mathrm{X}^{2}$ tabel pada df $1(\alpha=10 \%): 2,711$

dan $\alpha>0,05$. Hal ini dikarenakan data antar responden kurang bervariasi dengan nilai rata umur $(54,625$ tahun) dan standar deviasi $(12,38)$, rata-rata tingkat pendidikan (5,19 tahun) dan standar deviasi (2,29), rata-rata pengalaman (30,94 tahun) dan standar deviasi 9,21, ata-rata luas lahan $(0,38 \mathrm{Ha})$ dan standar deviasi $(0,29)$.

\section{c. Menganalisis Faktor-faktor yang \\ Menpengaruhi Pendapatan Usahatani Jagung. \\ Hasil uji regresi yang disajikan pada Tabel} 3 menunjukkan bahwa hasil produksi per hektar, biaya benih per hektar, dan jenis benih yang digunakan berpengaruh positif terhadap pendapatan usahatani jagung per hektar. Dibuktikan dengan nilai koefisien regresi bertanda positif dan $\mathrm{t}$ hitung $>\mathrm{t}$ tabel. Biaya pupuk per hektar dan biaya tenaga kerja per hektar berpengaruh negatif terhadap pendapatan usahatani jagung di daerah penelitian. Artinya setiap penambahan biaya pupuk dan biaya tenaga kerja dapat menurunkan pendapatan petani jagung di daerah penelitian. Sesuai dengan teori ekonomi, apabila biaya produksi semakin meningkat, maka pendapatan yang diterima petani cenderung menurun, dengan asumsi faktor lain dianggap konstan.

Tabel 3. Hasil Analisis Regresi Fungsi Pendapatan

\begin{tabular}{lrrr}
\hline \multicolumn{1}{c}{ Variabel } & Koefisien Regresi & t hitung & Sig. \\
\hline Konstanta & 18137.010 & .106 & .916 \\
H.Produksi $(\mathrm{Kg} / \mathrm{Ha})$ & $1140.042^{*}$ & 12.996 & .000 \\
B.Benih $(\mathrm{Rp} / \mathrm{Ha})$ & $.986^{* *}$ & 2.669 & .011 \\
B.Pupuk $(\mathrm{Rp} / \mathrm{Ha})$ & $-.833^{*}$ & -6.668 & .000 \\
B.Tenaga Kerja(Rp/Ha) & $-.935^{*}$ & -5.634 & .000 \\
Dummy Benih (Rp/Ha) & $682301.120^{*}$ & 4.236 & .000 \\
\hline $\mathrm{R}^{2}$ & & & 0,906 \\
\hline F hitung & & & 81.292 \\
\hline
\end{tabular}

\section{Keterangan:}

* : signifikansi pada taraf kepercayaan $99 \%$

*** : signifikansi pada taraf kepercayaan $90 \%$

$F_{\text {tabel }}$ pada df $1=4$ dan df $2=42(\alpha=1 \%): 3,80$

$\mathrm{F}_{\text {tabel }}$ pada df $1=4$ dan df $2=42(\alpha=10 \%): 2,08$

$t_{\text {tabel }}$ pada df $42(\alpha=5 \%)$

: 2,018

\section{Kesimpulan}

Pendapatan per hektar usahatani jagung hibrida lebih tinggi dibandingkan usahatani
** : signifikansi pada taraf kepercayaan $95 \%$

Variabel Dependen : Total pendapatan (Rp)

$\mathrm{F}_{\text {tabel }}$ pada df $1=4$ dan df $2=42(\alpha=5 \%): 2,59$

$\mathrm{t}_{\text {tabel }}$ pada df $42(\alpha=1 \%) \quad: 1,682$

$\mathrm{t}_{\text {tabel }}$ pada df $42(\alpha=10 \%) \quad: 2,698$

jagung non hibrida. Pendapatan usahatani jagung hibrida rata-rata sebesar Rp. 2.942.362.97/Ha sedangkan usahatani jagung 
non hibrida rata-rata sebesar Rp. 1.255.179,45/Ha.

Keputusan petani untuk menggunakan benih jagung hibrida dipengaruhi oleh faktor pendapatan usahatani dan kebutuhan pupuk. Artinya semakin tinggi tingkat pendapatan petani, akan semakin tinggi kecenderungan petani untuk memutuskan menggunakan benih jagung hibrida. Demikian juga dengan faktor kebutuhan pupuk. Sedangkan keikutsertaan kelompok tani berpengaruh negatif terhadap keputusan petani untuk menggunakan benih hibrida. Artinya petani yang mengikuti kelompok tani cenderung menggunakan jagung non hibrida.

Hasil produksi per hektar, biaya benih per hektar, dan jenis benih berpengaruh positif terhadap pendapatan usahatani jagung di daerah penelitian. Artinya semakin tinggi penggunaan variabel-variabel tersebut, semakin tinggi pendapatannya. Sedangkan biaya pupuk per hektar dan biaya tenaga kerja per hektar berpengaruh negatif terhadap pendapatan usahatani jagung. Artinya apabila terdapat penambahan biaya pupuk dan tenaga kerja, maka dapat menurunkan pendapatan petani jagung di daerah penelitian.

\section{Daftar Pustaka}

Dilla, Anisara Nasyahta. 2014. Analisis FaktorFaktor Yang Mempengaruhi Pengambilan Keputusan Petani Dalam Menggunakan Pupuk Organik Pada Komoditas Jagung Di Desa Wonorejo, Kecamatan Lawang, Kabupaten Malang. Skripsi. Universitas Brawijaya. Malang.

Hadijah. 2009. Identifikasi Usahatani Dan Pemasaran Jagung Di NTB. ISBN : 978979-8940-27-9

[online].http://balitsereal.litbang.pertanian .go.id/. Diakses pada tanggal 12 Januari 2015.

Makeham dan Malcolm. 1991. Manajemen Usahatani Daerah Tropis. Penerbit LP3ES. Jakarta.

Mubarakkan, dkk. 2012. Produktivitas Dan Mutu Jagung Hibrida Pengembangan Dari Jagung Lokal Pada Kondisi Input Rendah Sebagai Sumber Bahan Pakan Ternak Ayam. Volume 1 Nomor 1, Juni 201 ISSN: 2302 - 6715 [online]. http://repository.unib.ac.id/. Diakses pada tanggal 13 Januari 2015.
Sembiring, Hasil. 2015. Buku Pedoman Pelaksanaan GP-PTT 2015. Direktorat Jendral Tanaman Pangan. Jakarta.

Shinta, Agustina. 2011. Ilmu Usahatani. Penerbit Universitas Brawijaya Press. Malang.

Susenas BPS. 2014. Buletin Konsumsi Pangan. Pusat Data dan Sistem Informasi Pertanian. Jakarta.

UPT PPL Wajak. 2015. Laporan Tahunan Balai Penyuluhan Pertanian Wajak. WajakWarisno.1998. Jagung Hibrida. Penerbit Kanisius. Yogyakarta. 